Institute for Specialised Communication and Multilingualism, European Academy of Bolzano (EURAC)

\title{
WHEN LANGUAGE BECOMES LAW: THE METHODOLOGY AND CRITERIA ADOPTED BY THE SOUTH TYROLEAN TERMINOLOGY COMMISSION FOR THE STANDARDISATION OF GERMAN AND ITALIAN TRANSLATION EQUIVALENTS
}

\section{HISTORICAL BACKGROUND}

South Tyrol (Südtirol in German and Alto Adige in Italian) has been granted a special autonomy by the Italian state due to the presence of two language minorities in the area, a large German and a small Ladin speaking minority. South Tyrol's population is currently just above 500.000 (ASTAT 2013: 1). At the last official census in 2011 the distribution of the three language groups was $69.64 \%$ German native speakers, 25.84\% Italian native speakers and 4.52\% Ladin native speakers (ASTAT 2012: 4). ${ }^{1}$ In the present paper we will concentrate on the German speaking minority.

After World War I the County of Tyrol, until then part of the Austro-Hungarian Empire, was divided along the main Alpine ridge: the southern areas, known today as the provinces of Bolzano (or South Tyrol) and Trento, were annexed to the Kingdom of Italy. With the rise of Fascism in 1923 and of its nationalist and authoritarian ideology a period of "forced Italianisation" began in South Tyrol. The Fascist regime closed most German language schools, forbade German language classes, suppressed the local German press and strongly favoured the immigration of Italian speaking citizens from other regions. Italian was declared the official language and German fully banned from public life (Manuale dell'Alto Adige 2009: 23). At the end of World War II, the Italian and Austrian Ministers for Foreign Affairs signed an Agreement in Paris which was supposed to safeguard the rights of the German speaking population in South Tyrol. ${ }^{2}$ For the first time the German minority was

Authors' address: Institute for Specialised Communication and Multilingualism, European Academy of Bolzano (EURAC), Viale Druso 1, 39100 Bolzano, Italy. E-mail: echiocchetti@ eurac.edu, e-mail: nralli@eurac.edu, e-mail: istanizzi@eurac.edu

1 The figures refer exclusively to the Italian citizens residing on the South Tyrolean territory, who are asked to declare the language group they belong to on the occasion of every national population census.

2 The Paris Agreement was signed on 5 September 1946 by Alcide Degasperi for Italy and Karl Gruber for Austria. 
recognised as having the right to preserve its ethnic heritage and to pursue its economic and cultural development in the frame of autonomous executive and legislative powers. Herein lie the roots of South Tyrolean autonomy.

\subsection{The first Statute of Autonomy}

The First Statute of Autonomy, approved in January 1948, aimed at implementing the principles and obligations laid down in the Paris Agreement. In fact, even though the Statute declared a series of principles, such as the possibility of using the German language with the local public bodies and authorities (art. 85) and of teaching of the minority language in all schools (art. 15), it did not sufficiently enforce the guarantees envisaged by the Agreement. The use of the German language in the public administration, in court and especially with the police, remained very limited.

Serious problems ensued also from the decision to apply the Statute not only to the Province of Bolzano, where most minority language speakers resided, but to the entire region, comprising both the Provinces of Bolzano and Trento. However, the Province of Trento being largely Italian speaking, conferring broad decisional powers to the regional bodies instead of the provincial bodies gave the Italian speaking group a solid majority. As a consequence, many decisions concerning the language minority were weakened or made hardly effective. The German speaking population suffered strongly from the situation and reacted with fierce political and diplomatic struggles. Mainly during the 1960s and 1970s extremist groups even organised terrorist attacks and bombings in protest.

\subsection{The New Statute of Autonomy}

The 1948 Statute was discussed and revised for many years, until in 1972 the New Statute of Autonomy was released as Decree of the President of the Republic $n$. 670/1972. The main revolution in the New Statute is that article 99 confers the German language the same status as Italian. A more general principle explicitly grants equal rights to all citizens, whatever language community they belong to (art. 2). The German speaking citizens in the province of Bolzano are recognised as having the right to use their native language when dealing with the public administration and the bodies of the judiciary located in the province (art. 100). The main difference with the First Statute is that a mere possibility of using the minority language in public life becomes a fully-fledged right of the German speaking community.

16 years later, the Decree of the President of the Republic n. 574/1988 laid down several practical dispositions to regulate the daily use of German with the public authority. Such provisions, in particular those concerning trials to be held in German (or in the two official languages according to the parties' requests), stressed the urgent need for a complete and consistent legal and administrative terminology in German that would faithfully convey the concepts of the Italian legal system. To 
respond to this need, the Decree created a dedicated commission for terminology (art. 6), the Commissione Paritetica di Terminologia.

\subsection{The Terminology Commission and the standardisation workflow}

This Terminology Commission consists of six experts, three Italian and three German native speakers. The Italian speaking members are chosen by the Commissario del Governo, who represents the Italian state locally, whereas the German speaking ones are appointed by the local provincial government. Three of the members are translators, while the others are senior judges or lawyers. Their role is to determine and update or validate the legal, administrative and technical terminology used by the public authorities to ensure its correspondence in Italian and German. ${ }^{3}$ Also, the Commission is required to write and update a dictionary of legal, administrative and technical terminology in the two languages (DPR 574/88, art. 6, par. 1). The internal regulations stress that the Commission's main task is to decide the equivalent German language terms for the already existing Italian legal, administrative and technical terms and to determine - in the case of new terminology - the equivalent terms in both languages (art. 1).

The Commission works on the basis of accurate and complete terminology work (see 1.4), which they use to draft lists of bilingual terms (Fig 1.). These lists provide a translation equivalent for every Italian legal term. They treat thematically related concepts and are numbered progressively (e.g. list number 7 deals with the terminology of penal law, list number 8 with penal procedure law, etc.). The Commissario del Governo and the local government then receive the lists and have six months time to amend or integrate them where necessary. After this period, if no comment or complaint has been voiced by the two revising authorities, the lists are to be considered approved (DPR 574/88, art. 6, par. 2). At this point they can be published in the Official Journal of the Region and become legally binding. Every law, regulation, official document or provision drafted in both Italian and German after the publication should use the terminology established by the Commission.

3 Validating the already available bilingual terminology means making an explicit reference to existing publications or collections. The idea of bringing the terminology in use up-to-date aims at allowing a chance of correcting some terminological habits (cf. Palermo/Pföstl 1997: 16). 
Commissione Paritetica di Terminologia - DPR
574/1988/art. 6 Indirizzo segreteria comm. term. cjo Accademia Europea di Bolzano, via Weggenstein 12/a, 39100 Bolzano, tel. 0471/306117, fax 0471306199 Elenco terminologico $\mathrm{n} .5$

La commissione di terminologia ha approvato il seguente elenco di termini giuridici:

Termini di diritto civile e processuale civile

a causa di morte

a margine

a mero arbitrio

a pena di decadenza

a pena di nullità

a tergo

abbuono

abitazione (diritto di)

abrasione (in un documento)

abrogazione (di una legge)

abuso

accantonamento (nel bilancio)

accertamento

accertamento dell'obbligo del terzo (nella procedura esecutiva o per concessione di sequestro conservativo)

accertamento giudiziale

accertamento incidentale (riferito a questioni pregiudiziali)

accertamento tecnico

accertamento tecnico preventivo

\section{accessione}

accessione del possesso

accesso

accesso (diritto di accesso)
Paritätische Terminologiekommission - DPR 574/1988/Art. 6

Anschrift Sekretariat Ter. Komm. cjo Europäische

Akademie Bozen, Weggensteinstr. 12/a, 39100 Bozen, Tel. 0471/306117, Fax 0471306199

Terminologisches Verzeichnis Nr. 5

Die Terminologiekommission hat folgendes Verzeichnis von Rechtsbegriffen genehmigt:

Termini des Zivilrechts und des Zivilprozeßrechts

von Todes wegen

am Rand

nach freiem Belieben

bei sonstigem Ausschluß

bei sonstiger Nichtigkeit

auf der Rückseite

Gutschrift

Wohnungsrecht

Radierung (in einer Urkunde)

Aufhebung (eines Gesetzes)

Mißbrauch

Rückstellung

Feststellung

Feststellung der Verpflichtung des Dritten (im Vollstreckungsverfahren oder im Verfahren auf Sicherstellungsbeschlagnahme)

gerichtliche Feststellung

Zwischenfeststellung (auf Vorfragen bezogen)

fachkundliche Ermittlung

fachkundliche Ermittlung zu Zwecken der Beweissi-

cherung

Zuwachs (als Art des Eigentumserwerbs)

Anrechnung des Besitzes

Zugang, Zufahrt

Zutrittsrecht

Fig. 1: List of translation equivalents published on the Official Journal

\subsection{Terminology standardisation}

The activity of the Commission consists in terminology standardisation, as defined by the DIN standard (2342/1992: 5.4.2): "Normung von Begriffen und ihren Benennungen sowie von Begriffssystemen und den dazugehörigen Benennungssystemen oder Nomenklaturen". ${ }^{4}$ Their work is to officially validate single designations or entire concept systems with their "linguistic labels", i.e. the terms. The results are pairs of translation equivalents of legal and administrative terms in Italian and German that express - within the South Tyrolean context and the Italian legal system - exactly the same concept in both languages.

4 Standardisation of concepts and their designations as well as concept systems and the corresponding systems of designations or nomenclatures. 
Different requirements had to be considered when attempting to create a new German legal language for South Tyrol:

- newly created terms should reflect as much as possible the meaning expressed by the Italian terms;

- the new terms should respect the peculiarities and rules of the German language;

- the pre-existing and fully-fledged terminology of the other German speaking legal systems should be considered, as they might offer terms that can be adopted to designate Italian legal concepts or serve as a point of reference for the creation of sensible neologisms.

In addition to these sometimes conflicting requirements, it was of great importance to preserve the historical South Tyrolean terminology in the German language, which partly derives from the Austro-Hungarian period or was generated spontaneously out of an immediate need (Palermo/Pföstl 1997: 17) and can by now be considered established (e.g. terms like Grundbuch, a type of land registry of Austrio-Hungarian origin, translated into Italian as libro fondiario).

The work of the Terminology Commission allows to:

- determine 1-to-1 equivalences between terms in Italian and German, thus ensuring full terminological correspondence between the two language versions of legal and administrative texts;

- reduce the number of coexisting variants and synonyms, especially in German, thus curtailing the possible sources of misunderstandings and diverging interpretations;

- favour a clear, consistent and coherent communication, ensuring that both Italian and German native speakers may have access to legal texts.

The Terminology Commission needs qualified and professional input for their work. A group of terminologists composed of translators and legal experts at the Institute of Specialised Communication and Multilingualism of the European Academy of Bolzano elaborated the terminology entries which constitute the scientific basis for the Commission's work by:

- collecting relevant documentation and selecting the main concepts to be treated, together with the linguistic labels that are used to designate them (both in Italian and in South Tyrolean German);

- describing the legal concepts selected (through definitions, contexts of use, usage notes, etc.);

- conducting a contrastive analysis with the different German speaking legal systems;

- if necessary, elaborating translation proposals.

The contrastive analysis entails a comparison of the Italian concepts with the German speaking legal systems of Austria, Germany and partly also Switzerland and the European Union. The terminologists look for equivalent concepts in those legal systems and try to identify the linguistic labels that are used to designate them. ${ }^{5}$ In

5 For further information cf. also Sandrini (1996: $165 \mathrm{ff}$.) and Mayer (2000: 299 ff.). 
case no full equivalent can be found, differences are clearly explained, be they minor conceptual distinctions or essential differences in use. Such cases are anything but rare: for example, the concept piano di studio in Italian university law and its German South Tyrolean equivalent Studienplan both refer to the list of courses that university students are to take in order to obtain a university degree in Italy. The use of Studienplan is well consolidated in South Tyrol (possibly because it is a literal translation of the Italian term), but if compared with the identical term used in the Austrian legal system, some problems surface. In fact, the linguistic label is the same, but the concepts behind them differ greatly. In Austria Studienplan designates a regulation that disciplines how a university course is organised. Hence, the Austrian term expresses a concept that in Italian university law would be called regolamento didattico del corso di studio (DISAI 2007: 931). As a result, the two sides of the Alpine border use the same term to designate two different concepts. This can cause misunderstandings and problems in the relations and agreements between the two countries and also one of the reasons why accurate comparative terminological work prior to standardisation is so important.

If no consolidated South Tyrolean translations or foreign equivalents exist, the terminologists formulate a translation proposal, thus creating neologisms. Translation proposals can be loan words, newly coined words, loan translations or paraphrases (cf. Sacco 1992: 40-41; de Groot 1999: 27 ff.). In the case of loan words the Italian legal term is taken over and used as such also in German. A simple example is the term Carabinieri, which is used to designate this military corps in German as in the Italian language. Newly coined words are specific renderings of Italian legal terms to be used in South Tyrol. For instance, the administrative law concept atti contestuali (different administrative acts produced at the same time) was labelled zusammen abgefasste Verwaltungsakte. This being a typical Italian administrative concept, no equivalent could be found in other legal systems and a specific translation was formulated by creating a previously inexistent term. Loan translations are terms created with German words to translate the elements of an Italian term quite literally, e.g. assistente sociale $($ social worker) $=$ Sozialassistent, decreto ministeriale (Ministry decree $)=$ Ministerialdekret . In some cases even the syntactic structure of the source language is mirrored (see 2.1.6). The last strategy used to create translation proposals is paraphrasing. If the other systems have no comparable legal concept and no adequate translation is available, the original concept may be explained with a paraphrase: atto conservativo (an administrative act that aims at safeguarding a right) = Rechtshandlung zu Zwecken der Wahrung oder Sicherung eines Rechts, corruzione propria (bribery to obtain an unlawful administrative action) = Bestechung zur pflichtwidrigen Vornahme einer Amtshandlung, etc. Terminological conciseness gives way to a high degree of transparency, so as to help the citizens understand the concept behind the term. Nevertheless, the strategy of paraphrasing should be limited, since long and complex terms will be hardly accepted.

All the material produced by the terminologists is checked by sub-commissions of subject field experts for correctness, appropriateness, established use and desired use. 
The sub-commissions often review the definitions, select the preferred term among different competing translation proposals or revise and formulate themselves new translation proposals. Their task is to finalise the material to be submitted to the Terminology Commission. The work thus double-checked is then officially validated by the Terminology Commission (see 1.3).

\section{CRITICAL ANALYSIS OF STANDARDISATION CRITERIA ${ }^{6}$}

In the following sections we will analyse in detail which criteria the Commission has been adopting for their decisions (2.1) and illustrate the problems and critical aspects of the methodology applied (2.2). Some guiding criteria have been explicitly stated by the Commission while others have been deduced on the basis of their decisions.

\subsection{Standardisation criteria}

The Terminology Commission has followed a specific set of standardisation criteria during their work. A few were decided at the beginning, others as work progressed. Some criteria are inherently opposed (see 1.4) and the challenge is to find an adequate compromise for every single problematic term.

\subsubsection{Adopt the terminology used in the neighbouring German speaking countries}

Wherever possible, the Commission strives to adopt the terminology already existing in one or more German speaking legal systems. Should there be several terms that designate the same concept, the Commission tends to adopt either the German or Austrian term. For example, the concept of anno comune (common year) in university law is an equivalent of the German gemeinsames Jahr. There is no problem in accepting the same term for South Tyrol. As a third option, the European terminology is considered, while the Swiss terminology, being often quite different from a legal and linguistic point of view, can only rarely serve as a point of reference.

Doubts may arise when the terminology of the foreign legal systems could be adopted, but clashes against terminology which is already established locally, be it correct or not. The Italian government office that issues driving licences and registers vehicles is called motorizzazione civile. Despite the South Tyrolean translation zivile Motorisierung being largely used within the community, the Commission decided to validate Kraftfahrzeugwesen as the official translation. In this case the motivation was the desire to substitute a rather ugly loan translation with a linguistic label that would be closer to the terminology used in Germany.

\subsubsection{Select possibly transparent terms}

The Commission aims at choosing possibly transparent terms, i.e. terms whose meaning is immediately clear. The term abigeato (cattle raiding) in penal law is quite

6 Cf. also Chiocchetti et al. (2006), Chiocchetti/Stanizzi (2009, 2010), Ralli (2007), Ralli/Stanizzi (2008). 
difficult to understand even for an Italian native speaker. The equivalent German language compound validated by the Commission is Viehraub, whose elements Vieh (cattle) and Raub (robbery) immediately suggest the concept behind the term.

\subsubsection{Be consistent with already validated terminology}

One of the Commission's first concerns is to produce a uniform set of officially validated terminology. A high degree of conceptual and linguistic coherence with past decisions favours the dissemination and adoption of the proposed terminology by the end users, speeding up the process. For example, the official equivalent of delitto (a type of offence in penal law) being Verbrechen (in both the German and Austrian legal system), a series of hyponyms were constructed around the same term. The different types of delitto envisaged by Italian law have all been translated with a term that contains Verbrechen, e.g. delitto contro il matrimonio = Verbrechen gegen die Ehe, delitto contro il patrimonio $=$ Verbrechen gegen das Vermögen, delitto di comune pericolo $=$ gemeingefährliches Verbrechen, ${ }^{7}$ etc.

\subsubsection{Limit the use of Latinisms and other loan words}

This criterion stems from the general principles of transparency and simplicity of the standardised German translation equivalents. The Commission avoids validating Latin terms, even though these are frequent in the Italian legal language and almost as commonly used also in the German and Austrian legal systems. Latin expressions such as aberratio ictus, ius soli, mortis causa, petitum, etc. are well known by the German speaking lawyers. Nevertheless, the desire to help citizens understand the new terminology leads the Commissioners to translate or paraphrase most Latinisms used in the Italian legal system, e.g. aberratio ictus $($ transferred malice $)=$ Fehlgehen hinsichtlich des Zielobjektes, petitum (object of a legal action in civil law) $=$ Gegenstand des erhobenen Anspruchs, etc. The same principle is applied to all other foreign language terms. Up until now no English or other loan words from modern languages have been validated either.

\subsubsection{Limit the number of acronyms and initialisms}

This criterion also supports the creation of transparent translation proposals for a possibly large target group. For some bodies, taxes, roles etc., the acronym or initialism is widely used in Italian law, even more than the corresponding full forms. In German, the Commission has refused to create yet another short form and has validated only the complete translation, e.g. in administrative law ISTAT/Istituto Nazionale di Statistica (National Institute for Statistics) = Zentralinstitut für Statistik, in tax law ICI/imposta comunale sugli immobili (property tax on real estate levied at the municipal level) $=$ Gemeindesteuer auf Liegenschaften, etc.

7 These types of delitti refer to offences against the obligations of marriage (such as bigamy, for example), against property (e.g. theft) and offences that potentially endanger or damage a large number of people that cannot be determined in advance. 


\subsubsection{Favour the syntactic structure noun + genitive attribute before the com- pound noun}

A notable tendency of the Terminology Commission is their preference for the German translation equivalents that have the syntactic structure noun + genitive attribute instead of the corresponding compound form, even though the latter can be considered perfectly correct in German or is even the term that is commonly known in Germany and Austria. For the Italian term libertà di ricerca (freedom of research) the translation Freiheit der Forschung was preferred to Forschungsfreiheit. Also Aufnahme von Gesellschaftern (admission of new shareholders/partners) was chosen instead of Gesellschafteraufnahme as an equivalent of ammissione di soci. In both cases the compound terms are used in Austrian university law and German company law respectively.

\subsubsection{Eliminate ambiguities inherent in Italian terminology}

The Commission must take into consideration both the natural differences between Italian and German as well as the polysemous nature of some terms. For this reason they sometimes consider it necessary to distinguish the translations and add further specifications to the validated translation equivalents. These comments might refer to grammatical or semantic differences between the two languages. For example, in Italian law custodia (custody) can refer both to a person or an object. In the first sense it should be translated with Aufsicht, in the second with Verwahrung. The German translations validated by the Commission contain exactly those specifications in brackets: custodia = Aufsicht (auf eine Person bezogen), Verwahrung (auf eine Sache bezogen).

\subsubsection{Consider frequency of use}

The criterion of frequency of use is applied on the basis of experience, in order to choose between competing translations that are both correct from a legal and linguistic point of view. Validating the most frequently used alternative means respecting the more established term and thus speeding up the process of consolidation within the community of speakers (cf. Chiocchetti 2008: 26).

\subsubsection{Consider authoritativeness of the source}

One out of two or more competing terms that are linguistically and legally correct may be cited in a more authoritative source. For example, terms that have been used in the official translation of the legal codices or that are commonly used by the relevant offices. Choosing the translation proposed by an authoritative source fosters its acceptance within the community.

\subsection{Problems faced}

The standardisation activity definitely faces serious challenges due to the difficulty of respecting more than one need: linguistic correctness and coherence on the one hand, legal precision and accuracy on the other hand and, as a third requirement, respecting already established usage. As these needs might diverge, the desire to avoid doubts and 
imprecisions at the legal level prevails, even at the cost of standardising linguistically inelegant or cumbersome terms. See for example the translation of atto conservativo with Rechtshandlung zu Zwecken der Wahrung oder Sicherung eines Rechts (see 1.4).

Notwithstanding the obvious difficulty of this sort of "juggling", some of the criteria that have up until now been adopted by the Terminology Commission could be revised with the aim of reducing the number of inconvenient or incoherent translation equivalents, especially the criteria concerning loan words and acronyms. Latinisms are an important part of the legal language in civil law systems, even of growing importance as a lingua franca between legal experts with different backgrounds (Benke/Meissel 2002: $\mathrm{V}-\mathrm{VI})$. As the Italian lawyer will use the expression efficacia ex nunc, so will the German talk of Wirksamkeit ex nunc when the legal effects of a specific event occur starting from the moment it has happened, but not in the past (Benke/Meissel 2002: 125).

The legal language is not closed to loan words from languages other than Latin either. For example, Italian company law uses the term "holding" as much as German law refers to the same concept with the compound Holdinggesellschaft (literally: "holding society"). This is the reason why the Commission should probably revise the decision of not validating any loan words. The foreign term often reflects a well established usage and favours international exchanges.

In the same way, acronyms and initialisms serve linguistic efficiency and conciseness and may contribute to enhancing the readability of a text. It seems difficult to understand why the Commission should refuse to validate commonly used acronyms and initialisms, especially if we consider that the German speaking South Tyrolean community often ends up creating compounds which contain the Italian acronym and a German language specification. The German element actually expresses a concept that is already hidden behind a letter in the Italian acronym. For example, the compounds ICI-Gemeindesteuer and IRPEF-Steuer are commonly used for want of an equivalent German language acronym or initialism, where the German Steuer and the first Italian capital " $\mathrm{i}$ " for imposta express the same meaning (i.e. tax). ${ }^{8}$ The Commission should weigh the advantages and disadvantages in such cases before refusing to accept acronyms and initialisms.

Finally, one last problem consists in the belated constitution of the Commission with respect to the local situation (Palermo/Pföstl 1997: 37). In the 1970s and 1980s a local publisher printed a series called Blaue Reihe (Blue Series) consisting of the main Italian codices with their German parallel texts. Unfortunately, this work was not coordinated and supported by accurate and expert terminology work from the very beginning. The Commission was established only much later. As a consequence, not all the translation proposals made by the first translators of codices and drafters of local legislation can be considered correct (cf. Zanon 2008: 52).

8 The resulting compounds repeat the element expressing the fact that the term designates a tax. ICI means imposta comunale sugli immobili (see 2.1.5, a type of property tax on real estate levied at the municipal level) where imposta means "tax". The German language addition Steuer means "tax", too. The same happens with IRPEF-Steuer, which spelled out would become: imposta sul reddito delle persone fisiche-Steuer. 


\subsubsection{The need for constantly updated standardised terminology}

Legal systems are not static; part of the legislation is constantly amended or revised, e.g. because the regulation of a specific subject field needs to be adapted to a new and different situation. For example, in university law, the term laurea, which indicates the Italian university degree conferred upon a student at the end of his/her course of study was initially translated with Laureatsgrad by the Commission. However, this was done in the framework of the old Italian higher education system that has undergone a deep reform since 1999 with the introduction of a two-step degree. Whereas the old system provided for courses of study with a duration of generally four years (or in some cases five or six), with the reform students now obtain a bachelor's degree after three years of study. Two further years are necessary to achieve a master's degree. The linguistic label of each course of study had to be revised as explained in the following table:

\begin{tabular}{|l|l|l|}
\hline Concept & Italian & German \\
\hline $\begin{array}{l}\text { 4/6-year degree according to the old } \\
\text { higher education system }\end{array}$ & laurea & Laureat $^{9}$ \\
\hline 3-year bachelor's degree, new system & laurea or laurea triennale & Laureat \\
\hline 5-year master's degree, new system & $\begin{array}{l}\text { laurea magistrale or laurea } \\
\text { specialistica }\end{array}$ & Fachlaureat \\
\hline
\end{tabular}

\section{CONCLUSIONS}

Since the New Statute of Autonomy the German language legal terminology for South Tyrol has taken a huge step forward. Several translations of codices, important national laws and local legislation have been produced. However, creating a coherent, efficient and autonomous German legal language for South Tyrol is surely a long and daunting process that has not yet been completed.

South Tyrol has decided to face the problem with an official terminology standardisation effort. This has the advantage of providing coherent and precise high quality terminology, but also the negative effect of freezing the language in a certain moment of time, hindering its natural evolution, especially if updates are not taken care of timely nor widely disseminated.

Currently the quality of many texts produced by public authorities and private organisations can still not be considered fully adequate (cf. Zanon 2008: 52). Also, despite the official obligation to follow the Commission's terminological decisions, there are neither regulations nor sanctions ensuring their implementation ${ }^{10}$ (Palermo/Pföstl 1997: 23-32). The process of terminology standardisation followed by the Commission is quite complex; it aims at responding to the need for high quality terminology work

9 Previously Laureatsgrad, as explained above.

10 In fact it would be quite difficult to develop specific sanctions, given the difficulty of determining responsibilities for terminological mistakes or carelessness. Cf. Palermo/Pföstl (1997: 29-32) for a more in-depth analysis. 
and at enabling public bodies to communicate with the population on the basis of full conceptual equivalence between languages (Palermo/Pföstl 1997: 21). In the end it represents an extremely important tool for the effective protection of a language minority.

\section{Primary Sources}

ARNTZ, Rainer/Heribert PICHT/Felix MAYER ( $\left.{ }^{4} 2002\right)$ Einführung in die Terminologiearbeit. Hildesheim: OLMS.

CHIOCCHETTI Elena/Leonhard VOLTMER (eds) (2008) Normazione, armonizzazione e pianificazione linguistica/Normierung, Harmonisierung und Sprachplanung/ Normalisation, harmonisation et planification linguistique. Seminar proceedings, Bolzano, 8 February 2008. Bolzano: EURAC.

DE GROOT, Gerard-René/Rainer SCHULZE (1999) Recht und Übersetzen. Baden Baden: Nomos.

HILPOLD, Peter (1996) "Die rechtliche Stellung der Deutsch-Südtiroler in Italien." Europa Ethnica 53, 117-130.

PETERLINI, Oskar (2000) Autonomie und Minderheitenschutz in Südtirol und Trentino: Überblick über Land und Geschichte, Recht und Politik. Bozen: Präsidium des Regionalrates Trentino-Südtirol.

RALLI, Natascia (2005) "Terminologia comparata dei sistemi giuridici: problematiche principali." In: E. Banfi et al. (eds), Atti del $5^{\circ}$ Congresso dell'Associazione Italiana di Linguistica Applicata - Problemi e fenomeni di mediazione linguistica e culturale. Bari, 17-18 February 2005. Perugia: Guerra Edizioni, 113-128.

SANDRINI, Peter (1998) "Italienisches Recht in deutscher Sprache." In: P. Cordin/M. Iliescu/H. Siller-Runggaldier (eds), Italienisch und Deutsch im Kontakt und Vergleich: Akten des 7. Treffens der Italienischen und österreichischen Linguisten. Parallela n. 6, Dipartimento di Scienze filologiche e storiche dell'Università di Trento: Trento, 399-417.

ŠARČEVIĆ, Susan (1997) New approach to legal translation. The Hague: Kluwer Law International.

ZANON, Heinrich (2001) "Spurensuche 1999: Die deutsche Sprache bei Gericht in Südtirol.” In: K. Egger/F. Lanthaler (eds), Die deutsche Sprache in Südtirol. Einheitssprache und regionale Vielfalt. Wien/Bozen: Folio Verlag, 166-186.

\section{References}

ASTAT - Istituto provinciale di statistica della Provincia Autonoma di Bolzano - Alto Adige (2013) “Andamento demografico. $4^{\circ}$ trimestre 2012." Astat Info, n. 42. http://www. provinz.bz.it/pressnotes/module/pres getimg.asp?imgID=619945 [25 October 2013].

ASTAT - Istituto provinciale di statistica della Provincia Autonoma di Bolzano - Alto Adige (2012) "Censimento della popolazione 2011: Determinazione della consistenza dei tre gruppi linguistici della provincia di Bolzano." Astat Info, n. 38. http://www. provincia.bz.it/usp/285.asp?aktuelles_action=300\&aktuelles_image_id $=562948$ [25 October 2013]. 
BENKE, Nikolaus/Franz-Stefan MEISSEL (22002) Juristenlatein: 2800 lateinische Fachausdrücke und Redewendungen der Juristensprache. Wien: Manz.

CHIOCCHETTI, Elena/Natascia RALLI/Isabella STANIZZI (2006) "Normazione: aspetti giuridici e linguistici." Proceedings of the conference "La formazione in terminologia", 29-30 April 2006, Portico di Romagna. Mediazioni: Rivista online di studi interdisciplinari su lingue e culture. http://www.mediazioni. sitlec.unibo.it/images/stories/PDF_folder/document-pdf/3\%20chiocchetti.pdf [25 October 2013].

CHIOCCHETTI, Elena (2008) "Criteri di armonizzazione della terminologia della Convenzione delle Alpi.” In: E. Chiocchetti/L. Voltmer (eds), 19-30.

CHIOCCHETTI, Elena/Isabella STANIZZI (2009) "Kriterien zur Normung und Harmonisierung von mehrsprachiger Rechtsterminologie.” In: S. Šarčević (ed.), Legal Language in Action: Translation, Terminology, Drafting and Procedural Issues. Zagreb (HR): Nakladni zavod Globus, 167-182.

CHIOCCHETTI, Elena/Isabella STANIZZI (2010) “Die Beschlüsse der Südtiroler Terminologiekommission: Problematiken bei der Normung von Rechtstermini." In: C. Heine/J. Engberg (eds), Reconceptualizing LSP. Online proceedings of the XVII European LSP Symposium 2009. Aarhus, 1-9. http://bcom.au.dk/fileadmin/www.asb. $\mathrm{dk} /$ isek/chiocchetti stanizzi.pdf [25 October 2013].

DE GROOT, Gerard-René (1999) "Das Übersetzen juristischer Terminologie.” In: G. R. De Groot/R. Schulze (eds), Recht und Übersetzen. Baden Baden: Nomos, 11-46. DIN 2342 (October 1992) Begriffe der Terminologielehre. Grundbegriffe (Teil 1). Berlin/Köln: Beuth.

DISAI = RALLI, Natascia/Isabella STANIZZI/Tanja WISSIK (2007) Dizionario terminologico dell'istruzione superiore Austria-Italia/Terminologisches Wörterbuch zum Hochschulwesen Italien-Österreich (Deutsch-Italienisch). Bolzano: Provincia Autonoma di Bolzano - Ripartizione "Diritto allo studio, università e ricerca scientifica".

Giunta provinciale di Bolzano (ed.) $\left({ }^{21} 2009\right)$ Manuale dell'Alto Adige. Bolzano: Karo Druck.

MAYER, Felix (2000) "Terminographie im Recht: Probleme und Grenzen der Bozner Methode.” In: D. Veronesi (ed.), Linguistica giuridica italiana e tedesca/Rechtslinguistik des Deutschen und des Italienischen. Padova: Unipress, 295-306.

PALERMO, Francesco/Eva Maria PFÖSTL (1997) Normazione linguistica e tutela minoritaria/Minderheitenschutz durch Sprachnormierung. Bolzano: Accademia Europea.

RALLI, Natascia (2007) "Die Normierung aus terminographischer Sicht." In: D. Heller/P. Taino (eds), Italienisch-deutsche Studien zur fachlichen Kommunikation. Vol. 2, Deutsche Sprachwissenschaft in Italien. Peter Lang: Frankfurt am Main, 53-64.

RALLI, Natascia/Isabella STANIZZI (2008) "Il dietro le quinte della normazione." In: E. Chiocchetti/L. Voltmer (eds), 61-74.

SACCO, Roberto ( $\left.{ }^{5} 1992\right)$ Introduzione al diritto comparato. Torino: UTET. 
SANDRINI, Peter (1996) Terminologiearbeit im Recht. Deskriptver begriffsorientierter Ansatz vom Standpunkt des Übersetzers. Wien: TermNet. (IITF-Series, 8).

ZANON, Heinrich (2008) "Zur Problematik der Entwicklung einer deutschen Rechtssprache für Südtirol. Die Normierung durch die Paritätische Terminologiekommission.” In: E. Chiocchetti/L. Voltmer (eds), 49-59.

\title{
Abstract \\ WHEN LANGUAGE BECOMES LAW: \\ THE METHODOLOGY AND CRITERIA ADOPTED BY THE SOUTH TYROLE- AN TERMINOLOGY COMMISSION FOR THE STANDARDISATION OF GER- MAN AND ITALIAN TRANSLATION EQUIVALENTS
}

South Tyrol is a part of Northern Italy where a large German-speaking minority lives. In 1972 the local population was granted the right to use the minority language with the public administration, in court and in all realms of public life (DPR 672/1972). An urgent need for a clear and consistent German legal language that faithfully reflected the Italian legal system ensued. The task of responding to such "terminological emergency" was assigned to a commission of six legal experts and translators (DPR 574/1988), who were to officially validate (i.e. standardise) the German language equivalents to the existing legal and administrative Italian terms. The use of the newly standardised terminology is mandatory for all public bodies.

After about 20 years of activity, the proposed paper aims at analysing the results obtained and difficulties faced by the Commission during their daunting task of creating a German language terminology to express the concepts of Italian law with a constant view to the neighbouring well-established German speaking legal systems. The paper will illustrate the decision-making process, term selection criteria and strategies of neology as well as discuss the procedural problems and terminological inconsistencies on the basis of real examples.

Keywords: legal terminology, terminology standardisation, South Tyrol, Terminology Commission, language rights.

\author{
Povzetek \\ KO JEZIK POSTANE PRAVO: \\ METODOLOGIJA IN KRITERIJI JUŽNOTIROLSKE KOMISIJE ZA \\ STANDARDIZACIJO NEMŠKIH IN ITALIJANSKIH EKVIVALENTOV
}

Na Južnem Tirolskem, ki je del severne Italije, živi velika nemško govoreča manjšina. Leta 1972 je bila tej populaciji zagotovljena pravica do rabe maternega jezika v javni upravi, na sodišču in na vseh področjih javnega življenja (DPR 672/1972). Temu je sledila nujna potreba po jasnem in doslednem nemškem pravnem jeziku, ki bi ustrezno 
zrcalil značilnosti italijanskega pravnega sistema. Naloga reševanja nastale "terminološke nujnosti” je bila zaupana šestčlanski komisiji, sestavljeni iz pravnih strokovnjakov in prevajalcev (DPR 574/1988). Komisija je morala obstoječim pravnim in upravnim italijanskim terminom določiti nemške ekvivalente in jih tako standardizirati. Raba te novo standardizirane terminologije pa je postala zavezujoča za vse javne organe.

Avtorice v svojem prispevku analizirajo rezultate dela komisije in težave, s katerimi se ta že več kot dvajset let sooča pri oblikovanju take nemške terminologije, ki bi ustrezala pojmom italijanskega pravnega sistema, pri tem pa ima vseskozi pred očmi tudi uveljavljene pravne rede sosednjih nemško govorečih držav. Avtorice skušajo ponazoriti, kako potekajo odločitve komisije, kakšni so kriteriji za za izbiro terminov in kakšne so strategije pri oblikovanju neologizmov, ob tem pa s pomočjo konkretnih zgledov opozarjajo na proceduralne težave in terminološke nedoslednosti.

Ključne besede: pravna terminologija, terminološka standardizacija, Južna Tirolska, Terminološka komisija, jezikovne pravice. 